\title{
The Precarious Work of English Language Teaching in Canada
}

\section{Sherry Breshears}

This article draws from the concept of precarious employment to better understand the working conditions of teachers of adult English as an additional language (EAL) learners in Canada. I examine previously published research on the employment situations of this group of educators, drawing from data that have been gathered using interviews and surveys with teachers of adult English language and literacy learners over the past two decades. The findings of the review suggest that precarious employment in the form of part-time and temporary work, low wages, unpaid work hours, and multiple job holding is pervasive in this sector and that such conditions have persisted for decades. I propose that approaches developed in labour studies can assist in generating a better understanding of the ways that work insecurity affects these teachers' lives and pedagogical practices and suggest directions for further research into the intersections of working conditions and quality of education in this field. In particular, I suggest that precarious employment is produced by language and immigration policy frameworks and funding models and is linked to teacher and student identities. The article concludes by considering ways in which stakeholders can challenge employment insecurity and its associated precarity.

Cet article fait appel au concept de la précarité de l'emploi pour mieux faire comprendre les conditions de travail des professeurs d'anglais langue additionnelle (EAL) pour adultes au Canada. J'y jette un regard sur les recherches déjà publiées sur la situation de ce groupe d'éducatrices et d'éducateurs en matière d'emploi en m'appuyant sur des données obtenues dans le cadre d'entrevues et de sondages réalisés au cours des deux dernières décennies auprès de professeurs d'anglais langue seconde pour adultes et d'étudiantes et étudiants en alphabétisation. Les conclusions de cet examen indiquent que la précarité de l'emploi, qu'elle se décline sous forme de travail à temps partiel ou temporaire, de faibles salaires, d'heures de travail non rémunérées ou de cumul d'emplois, est omniprésente dans ce secteur, et que ce sont là des conditions qui persistent depuis des décennies. Je mets en avant que les approches développées dans le domaine des relations de travail peuvent nous aider à mieux comprendre les façons dont une telle insécurité d'emploi affecte la vie et les pratiques pédagogiques de ces enseignantes et enseignants, et ce, en suggérant des orientations pour des recherches plus poussées sur les points de rencontre entre les conditions de travail et la qualité de l'enseignement dans ce domaine. Je suggère en particulier que la précarité de l'emploi est le résultat des cadres de politique et des modes de financement en matière de langue et d'immigration et qu'elle est liée aux identités des enseignants et des étudiants. L'article 
se termine sur un examen des façons dont les intervenants peuvent remettre en cause l'insécurité d'emploi et la précarité qui lui est associée.

KEYWORDS: English language teaching, EAL teachers' employment, precarious employment

A fact of life for ESL educators is that we are marginalized; college ESL instructors are often hired as adjunct faculty on a semester by semester basis to teach non-credit preparatory courses in academic skills centers. Elementary ESL teachers teach in pull-out programs, traveling from school to school and setting up shop in closets, corridors, and basements. Adult educators teaching survival ESL have to work two or three jobs in order to survive; jobs with benefits, living wages, and any measure of security are few and far between.

(Auerbach, 1991, p. 1)

These words written by Elsa Auerbach close to 30 years ago present a snapshot of the working conditions for English language teachers at the time. To this day, this sense of professional marginalization as tied to employment conditions permeates the literature on the work of English language teachers. More recently, Yilin Sun (2010) wrote, "[l]arge multilevel classes, substandard facilities, intermittent funding, heavy teaching load, little professional status, and limited contracts with few benefits are factors that make up the context in which most ESOL practitioners work" (p. 151). It seems that even as the field of English language teaching (ELT) has grown over the years, little has changed in the working lives of teachers. Traditionally, the ELT field has positioned teachers' employment conditions as a concern that is linked to professionalism (Breshears, 2004; MacDonald, 2016; MacPherson, Kouritzin, \& Kim, 2005; Rappel, 2015; Sivell, 2005). Thus, to gain a glimpse into perceptions and experiences of adult English as an additional language (EAL) educators' working lives, one must wade through the scholarship on professional development and credentialing (Crandall, 1993; Wrigely, 1990), teachers' professional practices (Crookes \& Arakaki, 1999; Haque \& Cray, 2007), professionalism and identity (Johnston, 1997; Morgan, 2016; Rappel, 2015), and the professional status of the field (Burnaby, 2003; Crandall, 1993; MacDonald, 2016). The focus of this research tends to be on the conditions that enable instructors to perform the job of English language teaching well and for the occupation to gain greater credibility. The problem, however, is that the analyses produced within the professionalism framework have resulted in neither a perceptible improvement to the working conditions within ELT nor even a productive critique of how particular employment situations come to exist. An alternative framework is needed, one that links employment conditions within ELT to broader social, economic, and political factors 
to better illuminate ways of addressing working conditions and their effects on teachers' personal and working lives.

The purpose of this article is to consider the concept of precarious employment as a way of reframing our understanding of the work of English language educators in Canada. Precarious employment, a term that has developed in labour studies over the past two decades (Fudge \& Owens, 2006; Lewchuk et al., 2015; Procyk, Lewchuk, \& Sheilds, 2017; Vosko, 2006), refers to work that is "characterized by uncertainty, insecurity and a lack of control over how work is performed" (Lewchuk, Procyk, \& Sheilds, 2017, p. 3). This includes work that is temporary, part-time, low-paid, or lacking in benefits and collective representation. Approaches to understanding precarious employment offer tools for critically examining factors that contribute to job insecurity and for understanding the effects on individuals, families, and communities (Lewchuk et al., 2015; Lewchuk, De Wolff, King, \& Polanyi, 2006; Wilson \& Ebert, 2013).

I ask how the concept of precarious employment might be applied to generate new insights into work insecurity for teachers in adult EAL education. I begin by outlining central aspects of the concept of precarious employment and then examine previously published empirical data on the working conditions of EAL teachers of adults in Canada over the past two decades. Taken together, these studies suggest that part-time and temporary work, low wages, unpaid work hours, and multiple job holding, the hallmarks of precarious employment, are conditions that permeate the sector, and that such conditions have persisted for decades. I identify areas for further research to better understand how EAL teachers experience their employment situations on a personal and professional level. I also consider how the framework of precarious employment can provide new directions for understanding the social processes that produce employment insecurity for these teachers and look at strategies for challenging work insecurity in this education sector.

\section{What Is Precarious Employment?}

Precarious employment is work that is insecure in one or more ways. It includes "non-standard" work, meaning work that is temporary or part-time, as well as work that is low-paid, and lacking in benefits and collective representation (Fudge \& Owens, 2006; Strauss, 2017; Strauss \& Fudge, 2014; Vosko, 2006). Canada is currently seeing an increase in the proportion of jobs that are considered precarious in all sectors; however, from a historical perspective, precarious work is not a new phenomenon (Kalleberg, 2009; Quinlan, 2012; Vosko, 2006). In the 19th century, with expanding industrialization and a lack of market regulation, most jobs were unstable, and wages were low (Kalleberg, 2009, p. 3). Leading up to the Second World War, "insecure work was the norm in developed countries as unions had limited success in bargaining for steady work and governments did little to moderate the labour market 
effects of recessions and depressions" (Quinlan, 2012, p. 12). This period gave way to a time of increased recognition of the hardships experienced by workers and their families and a realization that such hardships led to negative health effects and social problems. A more stable form of employment, often termed the "standard employment relationship" (SER), emerged in response to the need to regulate labour practices for increased social stability and to promote economic growth.

The SER, conceived as "a stable, socially protected, dependent, full-time job the basic conditions of which (working time and pay) [are] regulated to a minimum level by collective agreement or labour law" (Fudge, 2009, p. 132), serves as the "normative model of paid employment" (Strauss \& Fudge, 2014, p. 1). As opposed to a flexible employment relationship based on short-term, market-oriented needs, the standard employment relationship "convey[s] a model of risk sharing in which fidelity to an employer over the life course [is] rewarded with continuous, full-time employment" (Strauss \& Fudge, 2014, p. 1). The standard full-time employment contract is typically augmented by social benefits including paid medical leave, health care benefits, and pension benefits. It is also supported by a policy and legal framework constituting obligations on the part of the employer as well as state-sponsored protections such as employment insurance. In wealthier countries, since the 1980s, there has been an overall decline in work characterized by the standard employment relationship, an increase in precarious forms of work, and an erosion of the social safety net.

Several researchers (Fudge \& Owens, 2006; Fudge \& Strauss, 2014; Peck, 1996; Vosko, MacDonald, \& Campbell, 2009) hold that the SER is a gendered phenomenon, based on the paradigm of a male breadwinner engaged in full-time paid work and supporting a family. Behind the scenes, this relies upon a female caregiver engaged in unpaid domestic work, an arrangement often referred to as the "gender contract." Strauss and Fudge (2014) argue that many studies of work do not take into consideration the "huge productive contribution that women make through their socially necessary, although unpaid, labour" (p. 16). As women seek to augment household work with paid labour, they often organize paid work around unpaid caregiving responsibilities. Thus, the labour market has become "hierarchically segmented according to gender" (p. 17). While more women are involved in full-time work than in the past, and while men are increasingly employed in precarious work, it is women, and especially racialized women, who are most likely to be engaged in part-time, contingent, and other precarious forms of employment, and these numbers are growing.

Vosko (2006) proposes a typology of forms of employment that are associated with job insecurity as a way to operationalize the idea of precarious work. The features can be linked to quantitative indicators, analyzed across studies, and probed for nuanced understandings. This typology situates employment forms on a continuum of greater or less precariousness. 
At the stable end of the continuum is full-time permanent employment, that which most resembles the SER. Precariousness increases with full-time temporary and part-time permanent work. The most precarious forms are part-time temporary and self-employed forms of employment. Conceiving of precarious employment as a continuum is a starting point for distinguishing types of employment that are at greater risk of insecurity on a number of fronts. One instance of how form of employment links to other dimensions of precariousness is eligibility for Employment Insurance in Canada, which is determined by the number of hours worked within a particular time frame. A person engaged in part-time work may be ineligible for full employment insurance benefits, and therefore may be more motivated to stay in a "bad job" to meet their financial needs. Thus, while such features are not deterministic, identifying less secure forms of employment provides a jumpingoff point for understanding the multiple and often complex aspects of work insecurity.

\section{The Studies}

I began this review by completing a scan of the scholarship on the employment situations of EAL teachers of adults in Canada. I selected eight studies that provided empirical data on the topic and then analyzed the findings for evidence of precarious employment. I discovered that forms of employment are often associated with work insecurity, including work that is temporary (casual and limited term), part-time, and low-paid, and jobs with minimal access to benefits and collective representation were common in the reports. I also found that insecure employment negatively affected instructors' teaching experiences and personal well-being. In the next section, I provide a rationale for the selection of and background to the studies.

\section{The Study Contexts}

The selected reports all examined the work experiences of teachers of adult learners from the late 1990s to the present day in Canada. One study (Sun, 2010) surveyed members of both Canadian and American EAL teaching communities. I have chosen this particular time frame and geographical location for several reasons. First, empirical research into the employment conditions of English language teachers did not emerge until the 1990s and still remains scant. Thus, to conduct a thorough review, as many studies as possible were brought into the scan. Presenting data from across the decades also allowed for observations around changes and continuities within the sector. Second, the selected studies are compatible with well-established methodological approaches to precarious work as they reported on matters such as work hours (part-time or full-time), certainty of ongoing work (temporary or permanent), and other relevant factors including access to benefits and 
union representation. Although a number of studies on working conditions for English language educators have emerged in other countries (Bowen, 2016; Crookes \& Arakaki, 1999; Johnston, 1997; Smith, Hofer, \& Gillespie, 2001), these were excluded from the scan, as my main goal was to provide a summary of the research on Canadian EAL teachers' employment situations, along with a brief examination of the specific institutional and funding contexts that influence the work of these educators. However, I will occasionally draw from research outside of Canada to point to areas for further exploration.

The teachers who participated in the studies were based in a range of institutional settings. Some teachers taught EAL at community-based organizations, while others taught adult basic education (ABE) to English language and literacy learners in school board programs. Both types of programs are funded primarily through government sources. Other institutional contexts included public colleges, universities, and private language schools, where programs often cater to income-generating international students. It is important to keep in mind that teachers may move between these sectors during their careers or even hold multiple jobs concurrently in different types of institutions (Valeo \& Faez, 2013).

Each study offered empirical data on the employment situations of adult language teachers. The studies were either survey-based, interview-based, or both. The largest sample size was a survey with more than 1,500 respondents (Power Analysis, 2000), and the smallest was a series of in-depth life history interviews with six respondents (Rappel, 2015). Four of the surveys had more than 1,000 respondents (Power Analysis, 2000; Sanaoui, 1997; Sun, 2010; Valeo, 2013). Regarding study participants, one characteristic stands out as consistent across the studies: The vast majority of respondents was female, ranging from $74 \%$ in White and Naylor (2015) to $87 \%$ in the Valeo and Faez (2013) and Sanaoui (1997) studies.

\section{Employment Conditions for English Language Teachers of Adults}

Low wages, a high reliance on part-time employment, uncertainty about ongoing work, threats of funding cuts, lack of adequate benefits, lack of administrative support, and excessive unpaid work were just a few of the employment concerns voiced in the studies. These conditions converged in the daily lives of teachers to create more or less bearable working situations. In this section, I will identify particular forms of employment presented in the reports that are typically associated with precarious employment and show how teachers experienced these forms of work. 


\section{Temporary Work}

Temporary employment is considered a key indicator of precarious employment as it creates a lack of predictability and may result in precarity in other areas of life. With this in mind, I reviewed the studies to gain an understanding of the prevalence of temporary work in the field and found that short-term work arrangements and the resulting sense of employment uncertainty were a central concern. In Sanaoui's (1997) survey of almost 1,200 EAL teachers in Ontario, only $24 \%$ had permanent teaching contracts. Respondents indicated that "all agency types employed more instructors on short-term contracts than permanent staff, except for colleges that employed a slightly larger number of permanent instructors" (pp. 43-44). In a survey commissioned by both the Canadian and Ontario governments (Power Analysis, 2000), the proportion of respondents with permanent contracts was only slightly higher at $29 \%$ (p. 62). The researchers in this study felt that "[f]unding is at the root of job security for teachers" (p. 74). For example, one teacher said, "When teachers have to hold their breath every 6 months to see if funding will be renewedit is very taxing on them as well as students." This feeling was echoed by a teacher in Valeo and Faez (2013): "It's very difficult to stay, to first get the position, and then to stay in that position for a long time because of all this uncertain budget and funding" (p. 13). In Sun's (2010) survey of more than 1,100 adult language and literacy teachers, almost $43 \%$ identified job insecurity as their primary employment concern. In addition, Sanaoui (1997) stated that "instructors' employment on [a] short-term basis hinders their opportunities to develop viable ESL programs" (p. 46), highlighting the crucial link between pedagogical practices and employment conditions.

\section{Hours of Work}

Next to temporary employment, part-time employment is a core characteristic of precarious work. Sun (2010) claimed that a "persistent concern in the adult education field has been the fact that full-time positions are scarce and the majority of teachers work part-time" (p. 145). This sentiment has been echoed by many others regarding the working conditions within adult EAL teaching communities (e.g., Auerbach, 1991; Crandall, 1993; Rappel, 2015). The findings of the studies bore this out. White and Naylor (2015) and Power Analysis (2000) reported that approximately half of their respondents were engaged in part-time employment while Sun (2010) reported even higher rates. Only 37\% of the respondents in Valeo (2013) were employed full-time, with $31 \%$ engaged in part-time work, and $21 \%$ not employed at the time of the survey. Half of the part-time teachers in White and Naylor (2015) indicated that they would prefer to be working more hours than their current schedule allowed, leading the researchers to contend that these educators were underemployed (p. 5). Some respondents in Sun (2010) commented that no instructors were ever hired on a full-time basis at their institutions, and 
one person speculated on the reason for this practice: "The program avoids paying benefits, so the maximum number of paid hours per week is fewer than $20^{\prime \prime}$ (p. 146).

\section{Salary and Wage}

Wage level is another important indicator of the scope of employment precariousness, a factor that, given the prevalence of part-time and temporary work arrangements in adult EAL education, could significantly affect work security for teachers. Sanaoui (1997) and Power Analysis (2000), both situated in Ontario, are the only studies included in this review that reported directly in wage levels, with both finding mean hourly rates to be above $\$ 28$ an hour at the time of the research. Institutional context seems to matter when it comes to wage rates; both studies showed that public colleges and universities provided better wage rates than private schools, community organizations, and school boards. Some of the studies reported only on teachers' perceptions of the adequacy of their wages, with many teachers reporting a lack of satisfaction with their income. Among overall work concerns, low wages ranked first in Sun's (2010) survey, where 50\% of respondents felt it was the primary issue with their employment. A respondent in the report by Valeo and Faez (2013) pointed out the link between income and multiple job holding, an issue that will be raised later in this article: "The big thing is salary. Salaries are quite low and people have to have two or more part-time jobs on a daily basis to survive financially" (p. 13).

Power Analysis (2000) indicated that unionized employees in their survey were likely to make a higher wage than those that were nonunionized. In addition, men in their study earned a higher hourly wage than women. These observations reflect broader tendencies in the Canadian context, where union representation generally ensures better compensation (Jackson \& Thomas, 2017, p. 208), and where male wages tend to outstrip female wages (Statistics Canada, 2018). Furthermore, this study showed that teachers on permanent contracts earned more than those on limited-term contracts, and that parttimers made less than any other category. Here, heightened precariousness associated with the intersections of gender, form of employment, and wage level comes into view.

\section{Unpaid Work}

While a mean rate of $\$ 28$ an hour as reported in Sanaoui (1997) and Power Analysis (2000) may not seem to indicate a low wage especially when adjusted for inflation, there is a strong prevalence of unpaid work in the reports, which bears directly upon the adequacy of the income package. Two essential and time-consuming yet often invisible components of teachers' work are hours spent preparing for teaching and grading student work. In addition, language teachers are often expected to engage in student advising, 
professional development, and committee work outside of paid hours. Such arrangements led to two major concerns for teachers in the studies: low rates of pay relative to hours worked and excessive working hours overall.

Sun (2010) noted that "many institutions still require adult education teachers to have 20-30 class contact hours per week, plus other professional obligations, in order to be considered as having a full-time workload" (p. 148). This, Sun claimed, deviated significantly from the number of contact hours in other disciplines at the same institutions, including foreign languages, in which instructors tended to teach about half the number of hours per week. Haque and Cray (2007) found that none of the teachers in their study was paid for work performed outside of teaching. One respondent explained, "When you look at the preparation time, I probably earn below minimum wage" (p. 639).

White and Naylor (2015) scrutinized in detail levels of both paid and unpaid hours in their study. They learned that more than two thirds of educators were not paid for preparation time (p. 7). Half of the teachers spent between 10 and $30 \mathrm{hr}$ per week in unpaid work time. For total time worked (paid and unpaid), almost a quarter of respondents worked between 41 and $50 \mathrm{hr}$ per week, and a tenth put in more than $50 \mathrm{hr}$ (p. 11). One participant stated, "It is the sheer workload that is killing me, especially as I teach a high ESL population, and I teach English. Marking an ESL essay takes more than twice as long as marking a native English speaker's essay" (p. 8). Another concern around unpaid work time was expressed in Rappel (2015). This study showed that teachers were often expected to put unpaid time into extracurricular activities "in order to remain in good standing within their workplace organizations" (p. 322). This condition was tied to teachers' employment status, "placing them in positions of having to extend their goodwill in order to seek continual reinstatement as temporary workers." This statement provides insight into the compounding effects of precarious work, where power imbalances may be amplified under precarious working conditions.

\section{Multiple Job Holding}

With so many teachers employed in part-time, temporary, and underpaid work, it is no surprise that some studies found a pervasive situation of multiple job holding. This may play a role in the fact that some teachers reported working more than the equivalent of full-time hours. Sun (2010) related that almost a third of survey participants worked for more than one program (p. 146). Reasons included the need to make a survival income, as well as for pleasure and enrichment. Haque and Cray (2007) linked low income to multiple job holding for teachers in their survey: "Those teachers who depended on their LINC [Language Instruction for Newcomers to Canada] teaching salaries as a main source of income had to supplement their income with other work" (p. 640). For those holding multiple teaching assignments 
in Valeo and Faez (2013), reasons included lack of full-time and permanent work, "thus working in more than one position to provide some degree of security" (p. 14).

\section{Access to Benefits}

Cranford and Vosko (2006) claimed that the "social wage" is intrinsic to the livability of the income package. This is "the bundle of elements beyond earnings, and it significantly shapes the standard of living of individuals and households as well as the relations of distribution within households" (p. 49). The specific practices at each workplace and the particulars of state-offered benefits are important for understanding the adequacy of teachers' benefits packages. For those in low-wage jobs, access to extended health care can make a significant difference to quality of life. With these variations in mind, the reports provide a glimpse into how adult EAL teachers are faring in terms of compensation through benefits.

Overall, employer-paid benefits were not widely available to the EAL educators who responded to the surveys. Of the reports that addressed benefits, Power Analysis (2000) showed the highest rate at 60\%, and Sanaoui (1997) showed the lowest rate at $42 \%$, with Sun (2010) falling in between these. Of the $60 \%$ of teachers with benefits in Power Analysis (2000), most received only one type of benefit, most commonly paid sick days. Power Analysis also found that instructors within the City of Toronto, college instructors, and full-time, permanent, and unionized employees had superior benefits packages to others. Teachers in both Sun (2010) and Power Analysis (2000) indicated that lack of benefits was a major concern.

For some teachers, provision of benefits signified reliable employment. In Valeo and Faez (2013), one participant stated, "full time work would be nice. I am sick of contract work with no benefits" (p. 13). There is a common association between full-time work and eligibility for benefits, illustrated in the instance above where an employer refused to retain teachers on a fulltime basis to avoid providing benefits (Sun, 2010, p. 146). These situations raise questions about the compounding effects of precarious employment in adult EAL teaching, where those in part-time and temporary work are ineligible for benefits, and, thus, precariousness becomes intensified.

\section{Effects of Precarious Employment on Teachers: Sense of Insecurity and Lack of Well-Being}

Not every teacher who works on a part-time or temporary basis experiences precarity. For some teachers, such an arrangement may be desirable given their life circumstances. However, as seen above, for many teachers, unpredictable schedules, low wages, part-time hours, and little access to benefits lead to precarity in other areas of life. Kalleberg (2009) looked at precarious 
employment as "perceived job insecurity" (p. 7); it reflects not just the status of one's employment relationship but encompasses what is at stake from the worker's point of view. Sanaoui's (1997) study suggested that $40 \%$ of teachers perceived their work to be insecure; instructors without collective agreements felt more insecure about their work than those with collective agreements, and part-time instructors felt less secure than full-time instructors (p. 45). As indicated above, in Sun (2010), lack of job security was a concern for $43 \%$ of respondents. One instructor expressed that this sense of insecurity is a result of underfunding: "[T]he never-ending threat of loss of funding. It's more than the job security-it's the constant of having to beg for money" (p. 152). For $75 \%$ of teachers in White and Naylor's (2015) study, job insecurity was the number one source of stress.

This lack of security also affected the wellness of teachers. For example, as was noted above, some teachers who held multiple jobs did so because their part-time and/or temporary contracts made meeting their daily survival needs unpredictable (Valeo \& Faez, 2013). However, multiple job holding is one way that the effects of precarious employment become compounded in people's work and personal lives, which may lead to negative impacts on health (Lewchuk et al., 2006). A sense of exhaustion and difficulty maintaining good health was expressed by Naylor (2015a): "Respondents spoke of their fatigue and, in some cases, ill-health because of their reports of 'doing more with less', constant layoffs, and lack of paid prep time" (p. 7).

Aside from negatively affecting an individual's physical and mental wellbeing, precarious employment affects whole families and communities, as "[i]nsecure jobs produce insecure households" (Wilson \& Ebert, 2013, p. 269; see also Lewchuk, Procyk, \& Shields, 2017). The data provided by the reports in this review provide little detail of the effects of insecure work on teachers' lives outside of work. However, an example from Haque and Cray (2007) illustrates how precarious employment is entangled with gendered dependencies beyond the workplace: "I have children. I have a husband who puts food on the table. I would not have this job if I needed to put food on the table" (p. 629).

\section{Effects of Precarious Employment on Teaching and Learning}

Some of the reports also reasoned that effective teaching is hindered by precarious working conditions. While Sun (2010) observed, in a general sense, that "[p]revious studies in adult education have shown that such precarious employment patterns undermine the professionalism of the field" (p. 142), Haque and Cray (2007) expressed more specifically that "low pay and lack of job security have an impact on how much time teachers can allocate not only to their teaching, but also to their own personal and professional development" (p. 640). Valeo and Faez (2013) made the similar point that "effec- 
tive instruction cannot be delivered by teachers who hold multiple teaching assignments and are unsure of the continuation of their job" (p. 15). However, aside from these brief observations, there is little empirical evidence in the studies of how quality of instruction is affected by precarious employment.

In addition to the ways that precarious employment may affect teachers' abilities to deliver quality instruction, work insecurity appears to be a significant factor in driving teachers away from the profession. Naylor (2015a) found that close to $40 \%$ of survey respondents were considering leaving the field before retirement. The main reasons were a sense of insecurity, fatigue, and the instability of the field (p. 6). Regarding early career adult EAL teachers, Valeo and Faez (2013) stated that their study results "suggested a high risk of attrition for ESL teachers due to lack of suitable employment opportunities" (p. 2). These researchers contemplated how teachers "deal with these conditions and what decisions they make in these contexts, decisions that sometimes include leaving the field altogether" (p. 7).

Further research on the effects of precarious employment for EAL teachers on the learning conditions for learners is needed, including the effects of teacher attrition. A study by Smith and Hofer (2003) with adult basic education teachers in the United States suggested that "high teacher turnover and teacher burnout were key reasons why students might leave" (p. 161). One teacher stated, "that's where the change in teachers is devastating, and that's when students drop out because they don't have the continuity that they need." This example shows how teachers' working conditions are closely entwined with students' learning situations and calls for a deeper understanding of this relationship in Canadian contexts.

\section{Protection against Employment Insecurity: Union Representation}

With this extensive evidence of precarious employment in the adult EAL sector, the question arises: What kinds of protections were in place for these teachers? Evidence shows that unions are key actors in helping workers exert control over the labour process, increasing job security, and raising wage levels (Anderson, Beaton, \& Laxer, 2006). However, few of the studies provided rates of union membership. Power Analysis (2000) showed that 42\% of respondents were union members and that those who were covered by a collective agreement had a higher average income than those who were not. This is consistent with Statistics Canada findings (as cited in Jackson \& Thomas, 2017, p. 211). Sanaoui (1997) reported that 39\% of respondents were in unions and that instructors who were not unionized felt less secure than those who were. This supports results from my own previous research with unionized EAL teachers who felt that the presence of a union increased their employment security (Breshears, 2008). 
Despite these findings, White and Naylor's (2015) study only included teachers employed for school boards across British Columbia, all of whom were members of the British Columbia Teachers' Federation. These teachers reported problematic working conditions such as "split shifts, reduced course assignments (for over one-quarter of respondents), no paid prep time (for over two-thirds of respondents), and the majority have minimal breaks, which are often used to assist students" (Naylor, 2015b, p. 4). These findings raise questions about the extent to which unions are able to mitigate precarious employment in adult EAL education and suggest the need for further research into the matter. Of interest would be detailed data that compare employment situations in both union and nonunion contexts and address such questions as, How does the presence of a union affect teachers' daily lives? What do teachers see as the benefits of having a collective agreement? How could unions better support adult EAL educators?

\section{Protection against Employment Insecurity: The Role of Professional Associations}

Professional associations are another potential source of strength and advocacy for EAL teachers. Federally and provincially based organizations such as TESL Canada, B.C. TEAL (Teaching of English as an additional language), and TESL Ontario exist to support teachers and students and to uphold standards in the field. But how do these organizations help to address problematic working conditions? Sun (2010) found that teachers wanted TESOL (Teaching English to Students of Other Languages, the largest international association of EAL professionals) to address wages, benefits, and employment security as its top advocacy priorities. Similarly, a TESL Ontario member survey showed teachers wanted more employment support from the organization (Valeo, 2013). However, Morgan (2016) argued that TESL Ontario has retreated from active engagement in teacher and student advocacy, so that "its scope and framing are notably more subdued and decidedly nonadversarial" (p. 718). Furthermore, not all are of the opinion that professional associations should take on an overtly political role. MacPherson, Kouritzin, and Kim (2005) contended that

[i]n contrast to unions or trade associations that organize to protect the rights, privileges, and interests of working members, optimally professional associations should safeguard the profession and the professional activity as a public good, even beyond the interests of individual members. (para. 3)

Although these authors acknowledge the need for professional associations to engage in advocacy in the interests of improved working conditions for teachers, I was unable to find evidence of this actually happening in Canada. 
These conflicting opinions suggest that further dialogue is needed within professional associations regarding their advocacy responsibilities.

\section{Directions for Further Research on Precarious Employment in Adult EAL Education}

The foregoing review of the literature on working conditions for adult EAL educators suggests that insecure employment may be widespread in this sector. The results of these eight studies consistently demonstrate that these educators experience high levels of part-time and temporary work, insufficient pay, extensive unpaid work, and multiple job holding as well as the compounding effects of work insecurity that play out on a personal and professional level. These findings may not be surprising to those who work in the field; many observers over the years have noted that the profession struggles with unacceptable employment conditions (Auerbach, 1991, 1992; Maley, 1992; Morgan, 2016). However, viewing these results as evidence of precarious employment generates new questions: Why is adult EAL teaching precarious in the first place? What characteristics of the profession result in precarious work for teachers? It is likely that the precarious employment of teachers is a symptom of deeper challenges in the field and that the insecurity felt by teachers is just as much a challenge for many employers and funders. Further to this, what can be done to mitigate these circumstances? Are there ways that teachers, administrators, and funders can work across the sector to bring more stability to the field? Such intricacies of the profession are underresearched, and further investigations into these and other questions are needed.

I suggest that the framework of precarious employment may help to bring about new understandings and new directions for research regarding this long-standing problem, thus opening the way for drawing upon diverse approaches to labour analysis. Proponents of the precarious employment framework advocate an understanding of work insecurity from multiple perspectives. Vosko (2006) promoted a multifaceted approach to understanding precarious employment, one that is "process-oriented, preoccupied with social relations and workers' experiences, interested in multiple dimensions and in continua rather than dichotomies, and attentive to social context and social relations" (p. 12). Likewise, understanding work insecurity in adult EAL education requires a range of conceptual frameworks and empirical methods that focus on personal perspectives as well as broader, structural influences.

One possible approach to further research is to see how teachers' work is shaped by program decisions, financial models, and policy frameworks, all of which may seem far removed from the local experiences of teachers. In Canada, relevant policy fields include federal immigration programs and the 
ongoing tension between the provinces and the federal government regarding responsibility for newcomer education (Haque, 2014; Mukhtar, Dean, Wilson, Ghassemi, \& Wilson, 2016; Robertson, 2013). While some researchers have provided analyses of adult language education policy in Canada and its effects on teachers (Burnaby, 2003; Eaton, 2013), such issues are largely avoided within the reports mentioned above. Exceptions include White and Naylor (2015), who drew connections between teachers' job insecurity and a provincial policy environment that creates instability in adult education, and Haque and Cray (2007), who drew links between LINC policy and teaching conditions. Aside from these, few studies probe the links between specific policy frameworks and EAL teachers' experiences of their work. The perceived distance between such policy fields and their effects on teachers' work may act to invisibilize the labour of EAL teaching. Until these social processes are traced and made visible, the struggles of EAL teachers may remain concealed from decision-makers.

Furthermore, there is little empirical research that connects financial arrangements with EAL teachers' work. That the field suffers from financial uncertainty seems to be a widely accepted fact, as Valeo and Faez (2013) make clear when they state that teachers "voiced concerns about working conditions and job security because of the economic instability of the field" (p. 13). These authors point to program-level decisions that destabilize teachers' work: "While part-time classes and short-term contracts may help programs provide flexible services, they may also undermine stability in the profession by making ESL teaching an untenable profession" (p. 15). Elsewhere, Eaton (2013) suggests that when larger postsecondary institutions have to deal with unpredictable financial arrangements, the risks are passed down to programs and teachers who bear these risks on a personal and professional level. Taken together, these statements suggest a feedback effect of precarious funding models, precarious employment, teacher attrition, and broad instability within the profession. A more thorough understanding of the policy and financial contexts that produce precarious employment in the field will help stakeholders to identify and address primary sources of instability.

Another approach to precarious employment asks that research be attentive to the social location of workers. This involves an awareness of how gender, racialization, and class play a role in differentiating social position in labour markets. As described above, historically, more women than men occupy precarious jobs. Moreover, "[w]omen are more likely than men to work for very low wages, and they continue to experience greater risk of poverty than do men" (Fudge, 2006, p. 13). In the absence of an attachment to a standard employment relationship, women are particularly vulnerable to the ill effects of precarious employment. Overall, approximately $80 \%$ of respondents to the studies reviewed here were female, suggesting that the teaching of EAL to adults is highly segmented according to gender. As noted above, a teacher in Haque and Cray (2007, p. 629) claimed she would be unable to feed 
her family on her EAL income and was dependent on her husband to provide for the family. As another example, in a study with language and literacy instructors in the United States, one respondent observed a connection between unpaid work hours and the expectations of women's labour:

I just don't see how you can expect people to commit to any kind of staff development and find out more about best practices when you pay them for four hours a week ... I don't go for paying someone 40 hours a week and expecting them to work 80 or paying them for 20 and expecting them to work 40 . I just don't believe in it and I think it's been done so much to women. (Smith, Hofer, \& Gillespie, 2001, para. 28)

All of these, including the one in the United States, provide us with questions about the ways in which gender organizes this profession in Canada. There is limited scholarship on the role of gender in the work of teachers in K-12 public schooling (e.g., Smaller, 2015; Urban, 2000). However, there is an even wider gap on this same topic in adult education. Further research into precarious employment in EAL may look to gender analysis in other femaledominated occupations, such as care work (Baines, 2015; Schwiter, Strauss, \& England, 2018), for ways of conceptualizing and investigating gendered divisions of labour.

Another way to see English language teachers' work as shaped by social location is to view this labour as entwined with the same social processes that act to marginalize adult English language learners. Once again, Elsa Auerbach's (1991) words from almost three decades ago ring true today: "We're marginalized because our students are marginalized, and their marginalization is necessary to keep the system functioning as it does. We are service workers to the academy so that our students can continue to be service workers to society" (p. 2). This perspective considers "the ways in which governments use immigration controls like a tap to regulate the flow of labor and control the type of worker that can enter the local labor 'pool' - and under what conditions" (Strauss, 2017, p. 6; see also Burnaby, 2008; Fleming, 2007). Immigration and education policies that position adult EAL learners as self-reliant human capital, not worthy of investment, have the invisible consequence of creating a precarious work environment for those who teach them. Research directions in this vein might trace immigration and adult education policy frameworks that position learners as workers-in-the-making (Haque, 2014; Robertson, 2013). A complementary approach would identify how students are positioned as consumers of commodified educational products, including English language skills (Chowdhury \& Le Ha, 2013; Park \& Wee, 2012; Robertson, 2013). Furthermore, investigations that tie racialized practices in English language education (Kubota \& Lin, 2006) to the value 
of teachers' work may also provide insights into the marginalization of EAL teaching.

A final suggestion for investigating the circumstances that contribute to precarious employment for adult EAL teachers is to bring a historical lens to the issue. It is clear that, as the temporal span of the eight studies shows, work insecurity has been a continuous concern for 30 years. It appears that while conditions within the sector are changing, such as recent increases in revenue-driven language education for international students in Canada (B.C. Council for International Education [BCCIE], 2016; Global Affairs Canada, 2016), impermanence has remained a consistent feature. It may be helpful to assess whether adult EAL teaching has followed the path of similar occupations that have experienced flexibilization, and to better understand why precarious employment is a constant in the sector within an evolving policy landscape.

\section{Moving Toward a System That Is More Just for Everyone}

A review of these eight studies on the employment experiences of English language instructors of adults produces a troubling image of an occupation that is permeated with job insecurity. Precarious work for this group of educators is not a simple phenomenon, but rather is entangled in complex social processes not the least of which is a climate in which work flexibilization is on the increase in industrialized nations (Lewchuk, Procyk, \& Sheilds, 2017). Employment conditions that have been common for adult educators for decades in North America are becoming the norm in many other sectors. In addition to growing employment insecurity, it is also widely accepted that modern life in general is becoming increasingly insecure, as social protections are continually being dismantled (Butler, 2015; Lorey, 2015; Waite, 2009). Lorey (2015) describes this more generalized precarity as "living with the unforeseeable, with contingency" (p. 1), not only in the realm of employment but in many other aspects of life. Butler contrasts living with precarity to living a "livable life" (2015, p. 33). But what does it mean to live a livable life, and how might adult EAL educators who are teaching in "unlivable" employment conditions get there?

Lorey (2015) states that in Butler's theory of precariousness, "what is problematized is not what makes everyone the same but rather what is shared by all [emphasis in original]" (p. 19). It is within these shared experiences of precarity for EAL teachers, their students, and others who are marginalized by the same policies and educational processes that opportunities emerge for the possibility that things might be different. Butler (2015) claims that to become visible and assert their collective needs, the precarious must come together and claim "a plural and performative right to appear" (p. 11). In this view, "plural enactments" (p. 18) coalesce around shared life circumstances and create "a bodily demand for a more livable set of economic, social and 
political conditions no longer affected by induced forms of precarity" (p. 11). This is what Butler refers to as "acting from and against precarity" (p. 58)1.

From this perspective, opportunities exist for adult EAL teachers working in diverse contexts to come together around their shared experiences to challenge precarious employment. A starting point for collective critique may be pre-service programs. Morgan (2016) questioned the common technicized approach to language instruction that is presented in teacher education to the exclusion of sociopolitical concerns. He put forth a "more politicized and nonconsensual approach to advocacy on behalf of TESOL, starting with the academic and professional development of new language teachers" (p. 728). His proposed model encourages teachers to engage directly with social justice issues. This approach helps build a community of teachers that is prepared to challenge unfair circumstances. Such a community may also help to break the sense of isolation often felt by novice instructors (Valeo \& Faez, 2013).

An example of collective mobilization in action is the work of Vancouver-based Education and Training Employees Association (ETEA), a union local within the Federation of Post-Secondary Educators. ETEA has been helping to organize private language schools and colleges in the area. The local formed in 1995 to address employment concerns for instructors at one private postsecondary institution in Vancouver. In 2007, recognizing common employment issues among teachers at other institutions, ETEA began to help other teachers form unions at their own schools. As a result of this, 12 sublocals have formed, and ETEA continues to provide employment and professional support to their members (Berry \& Worthen, 2012; ETEA, n.d.).

To make a final suggestion for how EAL instructors might organize around shared precarity, I again turn to the work of Elsa Auerbach, who pointed out that the labour processes of EAL teachers of adults are shaped by the same "educational processes that marginalize our students" (1991, p. 3), and that "we need to work collectively with each other in collaboration with students for a reconceptualization of the academy" (p. 7). This shared precarity forms the basis upon which to make the claim that "lives should be treated equally and that they should be equally livable" (Butler, 2015, p. 67). In Auerbach's view, acting on shared marginalization with learners includes engaging in critical pedagogy, but it also means going beyond the classroom to address the roots of precarity in teachers' and students' lives. EAL educators of adults could look to recent demonstrations in Ontario in which students stood with teachers to speak out about K-12 education budget and policy changes (Lewis, 2019). Through these bodily enactments (Butler, 2015), $\mathrm{K}-12$ teachers made the point that educational processes are inseparable from their labour and that both need to be properly sustained.

I end with a reminder that professional associations for EAL teachers, including TESL Canada, exist to uphold standards and promote excellence in teaching. Considering the findings presented in this article, however, the setting of standards and promotion of excellence may not be enough to 
create successful learning situations. Indeed, while some EAL professional associations seem to have pulled back from their advocacy role (Morgan, 2016), there is an opportunity here, perhaps even a responsibility, to become allies with teachers in advocating for more livable working conditions, for as Butler (2015) stated, "responsibility requires responsiveness, and that responsiveness is not a merely subjective state, but a way of responding to what is before us with the resources that are available to us" (p. 50). Protecting the well-being of teachers means protecting the quality of education for our students.

Note

1. Butler's (2015) "performative theory of assembly" builds on her earlier notion of identity as iteratively constituted. In reference to the question of collective agency, she explains that "none of us acts without the conditions to act" and that we may have to "act to install and preserve those very conditions" (p. 16).

\section{Acknowledgement}

I wish to thank Dr. Suzanne Smythe for her mentorship, Dr. Kelleen Toohey for her insightful feedback, and Dr. Kendra Strauss for her guidance with the Labour Studies literature. I am grateful to the editors at TESL Canada Journal and to the anonymous reviewers, whose careful reading and detailed feedback greatly strengthened the manuscript. And to all the English as an additional language (EAL) teachers out there, thank you for the work that you do.

\section{The Author}

Sherry Breshears is an interdisciplinary PhD candidate in Education and Labour Studies at Simon Fraser University. Her research focuses on the intersections of teachers' work, student learning, and educational policies, particularly in adult language and literacy education.

\section{References}

Auerbach, E. (1991). Politics, pedagogy, and professionalism: Challenging marginalization in ESL. College ESL, 1(1), 1-9.

Auerbach, E. (1992). Making meaning, making change. Participatory curriculum development for adult ESL literacy. McHenry, IL: Center for Applied Linguistics and Delta Systems, Inc.

B.C. Council for International Education (BCCIE). (2016). Economic impact of international education in British Columbia. Retrieved from http://bccie.bc.ca/wp-content/uploads/2016/03/201314-PostSecondary_Languages-Design_web.pdf

Baines, D. (2015). Neoliberalism and the convergence of nonprofit care work in Canada. Competition \& Change, 19(3), 194-209. https://doi-org/10.1177/1024529415580258

Berry, J., \& Worthen, H. (2012). Faculty organizing in the higher education industry: Tackling the for-profit business model. WorkingUSA, 15(3), 427-440. https://doi-org./10.1111/j.17434580.2012.00402.x

Bowen, Amanda. (2016). Sources of stress: Perceptions of South African TESOL teachers. Universal Journal of Educational Research, 4, 1205-1213. 10.13189/ujer.2016.040534.

Breshears, S. (2004). Professionalism and exclusion in ESL teaching. TESL Canada Journal: Special Issue, 4, 23-39.

Breshears, S. (2008). Stories of unionization: Four teachers' perspectives on collective bargaining in two Canadian private ESL schools (Master's thesis). Simon Fraser University, Burnaby, BC. Retrieved from http://summit.sfu.ca/item/9143 
Burnaby, B. (2003). ESL for adults and the status of those who teach them. Contact: Special Research Symposium Issue (p. 11-17). Retrieved from http://www.teslontario.net/uploads/publications/ contact/ContactSpring2003.pdf\#page $=12$

Burnaby, B. (2008). Language policy and education in Canada. In S. May \& N. H. Hornberger (Eds.), Encyclopedia of language and education (2nd ed., pp. 331-341). Boston, MA: Springer.

Butler, J. (2015). Notes toward a performative theory of assembly. Cambridge, MA: Harvard University Press.

Casas-Cortés, M. (2014). A genealogy of precarity: A toolbox for rearticulating fragmented social realities in and out of the workplace. Rethinking Marxism, 26(2), 206-226. http://doi.org/10.1 080/08935696.2014.888849

Chowdhury, R., \& Le Ha, P. (2014). Desiring TESOL and international education: Market abuse and exploitation (Vol. 37). Multilingual Matters.

Crandall, J. (1993). Professionalism and professionalization of adult ESL literacy. TESOL Quarterly, 27(3), 497-515. http://doi.org/10.2307/3587479

Cranford, C. J., \& Vosko, L. F. (2006). Conceptualizing precarious employment: Mapping wage work across social location and occupational context. In L. F. Vosko (Ed.), Precarious employment: Understanding labour market insecurity in Canada, 43-66. Montreal: McGillQueen's University Press.

Crookes, G., \& Arakaki, L. (1999). Teaching idea sources and work conditions in an ESL program. TESOL Journal, 8(1), 15-19. http://doi.org/10.1002/j.1949-3533.1999.tb00151.x

Eaton, S. E. (2013). The administration of English as a second language (ESL) program in higher education. In Y. Hebert \& A. A. Abdi (Eds.), Critical perspectives on international education (pp. 165-180). Rotterdam, Tapei: Sense Publishers.

Education and Training Employees' Association. (n.d.). About us. Retrieved from http:// eteaunion.org/

Fight for 15 and Fairness. (n.d.). Movement. Retrieved from https://www.15andfairness.org

Fleming, D. (2007). Adult immigrant ESL programs in Canada. In J. Cummins \& C. Davison (Eds.), International handbook of English language teaching (pp. 185-198). Boston, MA: Springer.

Fudge, J. (2009). The new workplace: Surveying the landscape. Manitoba Law Journal, 33(1), $131-149$.

Fudge, J., \& Owens, R. (2006). Precarious work, women, and the new economy: The challenge to legal norms. Oxford, England: Bloomsbury Publishing.

Global Affairs Canada. (2016). Economic impact of international education in Canada. Retrieved from http://www.international.gc.ca/education/report-rapport/impact-2016/index.aspx?lang=eng

Haque, E. (2014). Language training and labour market integration for newcomers to Canada. In L. F. Vosko, V. Preston, \& R. Latham (Eds.), Liberating temporariness?: Migration, work, and citizenship in an age of insecurity (pp. 201-217). Montreal: McGill-Queen's University Press.

Jackson, A., \& Thomas, M. (2017). Work and labour in Canada: Critical issues (3rd ed.). Toronto: Canadian Scholars Press.

Kalleberg, A. L. (2009). Precarious work, insecure workers: Employment relations in transition. American Sociological Review, 74(1), 1-22. https://doi-org./10.1177/000312240907400101

Kubota, R., \& Lin, A. (2006). Race and TESOL: Introduction to concepts and theories. TESOL Quarterly, 40(3), 471-493. https://doi-org./10.2307/40264540

Lewchuk, W., De Wolff, A., King, A., \& Polanyi, M. (2006). The hidden costs of precarious employment: Health and the employment relationship. In L. F. Vosko (Ed.), Precarious employment: Understanding labour market insecurity in Canada (pp. 141-162). Montreal: McGillQueen's University Press.

Lewchuk, W., Lafleche, M., Procyk, S., Cook, C., Dyson, D., Goldring, L., Lior, K. Meisner, A., Shields, J., Tambureno, A., \& Viducis, P. (2015). The precarity penalty: Poverty and employment precarity in Southern Ontario. Hamilton, ON: McMaster University. 
Lewchuk, W., Procyk, S., \& Sheilds, J. (2017). Origins of precarity: Families and communities in crisis. In S. Procyk, W. Lewchuk, \& J. Sheilds (Eds.), Precarious employment: Causes, consequences and remedies (pp. 2-15). Halifax: Fernwood Publishing.

Lewis, M. (2019, April 6). Teachers, students rally at Queen's Park to protest proposed education cuts. Toronto Star. Retrieved from https://www.thestar.com/news/gta/2019/04/06/unions-tohold-rally-at-ontario-legislature-to-protest-education-cuts.html

Lorey, I. (2015). State of insecurity: Government of the precarious. London: Verso Books.

MacDonald, J. (2016). The margins as third space: EAP teacher professionalism in Canadian universities. TESL Canada Journal, 34(1), 106-116. https://doi.org/10.18806/tesl.v34i1.1258

MacPherson, S., Kouritzin, S., \& Kim, S. (2005). Profits or professionalism: Issues facing the professionalization of TESL in Canada. College Quarterly, 8(2). Retrieved from http://eric. ed.gov/?id=EJ846488

Maley, A. (1992). An open letter to "the profession": Via the editor of ELT Journal, ELT Journal, 46(1), 96-99. https://doi.org/10.1093/elt/46.1.96

Morgan, B. (2016). Language teacher identity and the domestication of dissent: An exploratory account. TESOL Quarterly, 50(3), 708-734. https://doi-org/10.1002/tesq.316

Mukhtar, M., Dean, J., Wilson, K., Ghassemi, E., \& Wilson, D. (2016). "But many of these problems are about funds ...": The challenges Immigrant Settlement Agencies (ISAs) encounter in a suburban setting in Ontario, Canada. Journal of International Migration and Integration, 17(2), 389-408.

Naylor, C. (2015a). Chapter 5: Adult educators' views on working conditions and sources of stress. Adult Education in BC's public schools: Lost opportunities for students, employers, and society-A BCTF study of working and learning conditions. British Columbia Teachers' Federation. Retrieved from https://bctf.ca/AdultEducationStudy/

Naylor, C. (2015b). Chapter 9: Implications and possible directions for BCTF advocacy in support of Adult Education in public schools-A discussion paper. Adult Education in BC's public schools: Lost opportunities for students, employers, and society-A BCTF study of working and learning conditions. British Columbia Teachers' Federation. Retrieved from https://bctf.ca/ AdultEducationStudy/

Park, J. S.-Y., \& Wee, L. (2012). Markets of English: Linguistic capital and language policy in a globalizing world. New York, NY: Routledge.

Peck, J. (1996). Work-place: The social regulation of labor markets. New York, NY: Guilford Press.

Power Analysis Inc. (2000). Study of ESL/FSL Services in Ontario. Retrieved from http://atwork. settlement.org/downloads/linc/ESLFSL.pdf

Procyk, S., Lewchuk, W., \& Sheilds, J. (Eds.). (2017). Precarious employment: Causes, consequences and remedies. Halifax: Fernwood Publishing.

Quinlan, M. (2012). The "pre-invention" of precarious employment: The changing world of work in context. The Economic and Labour Relations Review, 23(4), 3-24. http://doi. org/10.1177/103530461202300402

Rappel, L. J. (2015). Integrating the personal and the professional marking the career paths of adult language educators. Adult Education Quarterly, 65(4), 313-325. http://doi. org $/ 10.1177 / 0741713615585573$

Robertson, S. (2013). Transnational student-migrants and the state: The education-migration nexus. Houndmills, Basingstoke, Hampshire, England: Palgrave Macmillan.

Sanaoui, R. (1997). Professional characteristics and concerns of instructors teaching English as a second language to adults in non-credit programs in Ontario. TESL Canada Journal, 14(2), 32-54. https://doi.org/10.18806/tesl.v14i2.684

Schwiter, K., Strauss, K., \& England, K. (2018). At home with the boss: Migrant live-in caregivers, social reproduction and constrained agency in the UK, Canada, Austria and Switzerland. Transactions of the Institute of British Geography, 1-15. https://doi-org/10.1111/tran.12235

Sivell, J. (2005). Second language teacher education in Canada: The development of professional standards. TESL-EJ, 9(2), n2. Retrieved from http://www.tesl-ej.org/pdf/ej34/a1.pdf 
Smaller, H. (2015). Gender and status: Ontario teachers' associations in the nineteenth century. In N. Bascia (Ed.), Teacher Unions in Public Education (pp. 11-31). New York, NY: Palgrave Macmillan.

Smith, C., \& Hofer, J. (2003). The characteristics and concerns of Adult Basic Education teachers. NCSALL (Report \#26). National Center for the Study of Adult Learning and Literacy (NCSALL). Retrieved from http://eric.ed.gov/?id=ED508605

Smith, C., Hofer, J., \& Gillespie, M. (2001). The working conditions of adult literacy teachers: Preliminary findings from the NSCALL staff development study. Focus on Basics, 4. Retrieved from http://www.ncsall.net/index.html@id=291.html

Smythe, S., \& Butterwick, S. (2017, June). A conceptual framework for studying adult education work on the frontlines. Proceedings of the 36th Annual Canadian Association for the Study of Adult Education Annual Conference (pp. 323-329). Toronto, ON: CASAE. Retrieved from https://www.dropbox.com/s/101zqqy7v0meldw/2017_CASAE_Proceedings.pdf?dl=0

Statistics Canada. (2018, November 23). The Gender Wage Gap and Equal Pay Day, 2018. Ottawa: Statistics Canada. Retrieved from https://www150.statcan.gc.ca/n1/pub/89-28-0001/2018001/ article/00010-eng.htm

Strauss, K., \& Fudge, J. (2014). Temporary work, agencies and unfree labour: Insecurity in the new world of work. In J. Fudge and K. Strauss (Eds.), Temporary work, agencies and unfree labour (pp. 1-25). New York, NY: Routledge.

Strauss, K., \& McGrath, S. (2016). Temporary migration, precarious employment and unfree labour relations: Exploring the "continuum of exploitation" in Canada's Temporary Foreign Worker Program. Geoforum, 78, 199-208. https://doi.org/10.1016/j.geoforum.2016.01.008

Strauss, K. (2017). Labour geography 1: Towards a geography of precarity? Progress in Human Geography. https://doi.org/10.1177/0309132517717786

Sun, Y. (2010). Standards, equity, and advocacy: Employment conditions of ESOL teachers in adult basic education and literacy systems. TESOL Journal, 1(1), 142-158. https://doiorg/10.5054/tj.2010.215135

Urban, W. (2000). Gender, race and the National Educational Association: Professionalism and its limits. New York, NY: Routledge Falmer.

Valeo, A., \& Faez, F. (2013). Career development and professional attrition of novice ESL teachers of adults. TESL Canada Journal, 31(1), 1-19. https://doi.org/10.18806/tesl.v31i1.1164

Valeo, A. (2013). The TESL Ontario member survey: A brief report. Contact Magazine, 39(1), 19-32. Retrieved from http://www.teslontario.org/uploads/pinterest/contactarticles/Survey_Valeo. pdf

Vosko, L. F. (Ed.). (2006). Precarious employment: Understanding labour market insecurity in Canada. Montreal: McGill-Queen's University Press.

Vosko, L. F., MacDonald, M., \& Campbell, I. (Eds.). (2009). Gender and the contours of precarious employment. London: New York, NY: Routledge.

Waite, L. (2009). A place and space for a critical geography of precarity? Geography Compass, 3(1), 412-433. https://doi.org/10.1111/j.1749-8198.2008.00184

White, M., \& Naylor, C. (2015). Chapter 4: Working conditions and workload issues in Adult Education. Adult Education in B.C.'s public schools: Lost opportunities for students, employers, and society. British Columbia Teachers' Federation. Retrieved from https://bctf.ca/uploadedFiles/ Public/Issues/Worklife/AdultEd/BCTFAdultEdStudy2015.pdf

Willett, J., \& Jeannot, M. (1993). Resistance to taking a critical stance. TESOL Quarterly, 27(3), 477-495. https://doi.org/10.2307/3587478

Wilson, S., \& Ebert, N. (2013). Precarious work: Economic, sociological and political perspectives. The Economic and Labour Relations Review, 24(3), 263-278. https://doi. org/10.1177/1035304613500434 